R.K. Batra MD, Veena Gulaya MD,

Rashmi Madan MD, Anjan Trikha MD

\title{
Anaesthesia and the Sturge-Weber syndrome
}

\begin{abstract}
We report a series of 13 patients with Sturge-Weber syndrome anaesthetised on 17 occasions. Anaesthesia management varied depending on the clinical manifestations which ranged from localized, superficial skin lesions to extensive systemic involvement. These patients tolerate anaesthesia well but anaesthetic management includes evaluation for associated anomalies. Difficulty with intubation may occur due to angiomas of the mouth and upper airway. Anaesthesia should be planned to avoid trauma to the haemangiomata and increases in intraocular and intracranial pressure.
\end{abstract}

Nous rapportons une série d'observations concernant des porteurs du syndrome de Sturge-Weber anesthésiés à 17 occasions. L'anesthésie a varié selon les manifestations cliniques qui allaient de la lésion superficielle localisée à l'atteinte systémique grave. Ces patients tolèrent bien l'anesthésie mais celle-ci nécessite une recherche des anomalies associées pour fin d'évaluation. La présence d'angiomes de la bouche et des voies respiratoires supérieures peut rendre lintubation difficile. La planification de l'anesthésie doit inclure la prévention du traumatisme aux hémangiomes et de l'augmentation de la tension intraoculaire et cérébrale.

Sturge (1879) ${ }^{1}$ first described the clinical features of the disease, whereas Weber (1929) ${ }^{2}$ demonstrated the pattern of intra-cranial calcification and named it encephalofacial angiomatosis. The characteristic features include an angiomatous malformation of the skin, usually in the distribution of the branches of trigeminal nerve and a similar vascular anomaly of the ipsilateral cerebral hemisphere. The resultant ischaemia gives rise to convulsions, hemiplegia, hemicerebral-atrophy and mental retardation.

\section{Key words}

ANAESTHETIC TECHNIQUES: general anaesthesia; SYNDROMES: Sturge-Weber.

From the Department of Anaesthesiology, All India Institute of Medical Sciences, Ansari Nagar, New Delhi 110029 , India.

Address correspondence to: Dr. R.K. Batra, 5/11 West Patel Nagar, New Delhi 110008, India.

Accepted for publication 7th October, 1993.
Other manifestations include ocular anomalies such as congenital glaucoma, varicosities of the retinal vessels, haemangioma of choroid, retinal detachment and optic atrophy.

Angiomas may be found on the trunk and extremities and can also involve the mucous membrane of the lip, nose, palate, tongue, larynx and trachea. Uncontrolled haemorrhage may result from the rupture of angiomas. Secondary metabolic changes, gangrene of the colon from circulatory insufficiency and haematemesis from gastric haemorrhage have been reported. ${ }^{3-5}$

As there are no previous reports of anaesthesia in patients with the Sturge-Weber syndrome, ${ }^{6}$ we describe our experience with 13 patients.

\section{Methods}

Thirteen patients with Sturge-Weber syndrome, aged from one month to $15 \mathrm{yr}$, presented for anaesthesia 17 times for various procedures on the eye, lip and palate over a period of eight years, from 1984 to 1992. Patients' characteristics are described in the Table.

Preoperative examination was performed to determine the involvement of the central nervous system and ear, nose and throat (ENT). A brain CT scan was done in a few cases to determine the extent of vascular changes and calcifications in the cerebral hemisphere.

Children of less than three years were premedicated with promethazine syrup $3 \mathrm{mg} \cdot \mathrm{kg}^{-1}$ or trimeprazine syrup $3 \mathrm{mg} \cdot \mathrm{kg}^{-1}$. Older children received pethidine 1 $\mathrm{mg} \cdot \mathrm{kg}^{-1}$ and promethazine $0.5 \mathrm{mg} \cdot \mathrm{kg}^{-1}$ im one hour preoperatively. Anti-convulsant medication was continued until the day of surgery.

Ten patients were submitted to anaesthesia for short procedures; nine for examination of the eye under general anaesthesia (EUA), and one for cyclocryo-therapy. Induction was performed with $\mathrm{O}_{2}: \mathrm{N}_{2} \mathrm{O}$ (33:67) and halothane 1-3\%. Spontaneous respiration was maintained with a face mask attached to Ayre's T-piece modified by Jackson Rees or Bain's circuit.

Five patients were operated upon for trabeculectomy and trabeculotomy and one patient for repair of cleftlip and cleft palate on two separate occasions. For these patients, anaesthesia management varied according to their age. In children up to three years $(n=3)$, inhalational induction was performed, using $\mathrm{O}_{2}: \mathrm{N}_{2} \mathrm{O}$ (50:50) and halothane $1-3 \%$ to facilitate tracheal intubation. Suc- 
TABLE Patients' characteristics

\begin{tabular}{|c|c|c|c|c|c|c|c|c|}
\hline $\begin{array}{l}\text { Age } \\
(y r)\end{array}$ & Sex & $\begin{array}{l}\text { Port wine } \\
\text { stain - } \\
\text { face side }\end{array}$ & $\begin{array}{l}\text { Other } \\
\text { haemangiomas } \\
\text { site }\end{array}$ & Hypertrophy & Convulsions & Glaucoma & $\begin{array}{l}\text { Other } \\
\text { anomalies }\end{array}$ & $\begin{array}{l}\text { Surgical } \\
\text { procedure }\end{array}$ \\
\hline $1 / 12$ & $\mathbf{M}$ & $\mathbf{R}$ & - & - & - & + & - & EUA \\
\hline $3 / 12$ & $\mathbf{M}$ & $B / L$ & - & - & - & - & - & EUA \\
\hline $3.5 / 12$ & $\mathbf{M}$ & $\mathbf{R}$ & - & - & - & + & L facial palsy & EUA \\
\hline $4 / 12$ & $\mathbf{F}$ & $\mathbf{R}$ & L leg & L leg & + & $t$ & $\begin{array}{l}\text { Talipus } \\
\text { Equinovarus }\end{array}$ & $\begin{array}{l}\text { Trab \& Trab } \\
\text { EUA }\end{array}$ \\
\hline $10 / 12$ & $\mathbf{F}$ & $\mathrm{L}$ & $R$ half of the body & - & + & + & - & EUA skin biopsy \\
\hline $11 / 12$ & $\mathbf{M}$ & $\mathrm{B} / \mathrm{L}$ & Whole body & L half of the body & + & + & - & EUA \\
\hline 2 & $\mathbf{M}$ & $\mathbf{R}$ & - & - & - & + & - & $\begin{array}{l}\text { EUA } \\
\text { Trab and Trab }\end{array}$ \\
\hline 3 & $\mathbf{M}$ & $\mathbf{R}$ & $\begin{array}{l}\mathrm{L} \text { half of the body } \\
\text { and soft palate }\end{array}$ & $L$ half of the body & + & - & Cleft lip and palate & $\begin{array}{l}\text { Repair of Cleft lip and } \\
\text { palate }\end{array}$ \\
\hline 7 & $\mathbf{M}$ & $\mathbf{R}$ & - & Face $-\mathbf{R}$ half & - & + & Mental retardation & Trab and Trab \\
\hline 8 & $\mathbf{F}$ & $\mathrm{L}$ & Both upper limbs & - & + & + & - & Trab and Trab \\
\hline 10 & $\mathbf{F}$ & $\mathrm{B} / \mathrm{L}$ & - & - & - & + & - & EUA \\
\hline 11 & $\mathbf{M}$ & $\mathrm{B} / \mathrm{L}$ & - & - & + & - & - & EUA \\
\hline 15 & $\mathbf{M}$ & $\mathbf{R}$ & $\begin{array}{l}\text { Whole body, hard } \\
\text { and soft palate }\end{array}$ & Face - $\mathrm{R}$ half & - & + & Mental retardation & $\begin{array}{l}\text { Trab and Trab } \\
\text { Cyclo-cryo }\end{array}$ \\
\hline
\end{tabular}

R - right, L - left, B/L bilateral, EUA - examination of eye under anaesthesia.

Trab and Trab - trabeculectomy and trabeculotomy.

Cyclo-cryo - cyclocryotherapy.

cinylcholine was used in doses of $1.5 \mathrm{mg} \cdot \mathrm{kg}^{-1}$ in one patient scheduled for lip and palate repair, and two other patients received vecuronium $0.1 \mathrm{mg} \cdot \mathrm{kg}^{-1}$. For three patients, aged seven years and above, induction of anaesthesia was performed with thiopentone $4-5 \mathrm{mg} \cdot \mathrm{kg}^{-1}$ iv followed by succinylcholine $1.5 \mathrm{mg} \cdot \mathrm{kg}^{-1}(n=2)$ or vecuronium $0.1 \mathrm{mg} \cdot \mathrm{kg}^{-1}(n=1)$. The larynx was sprayed with lignocaine $4 \%$, before tracheal intubation which was performed with a well-lubricated endotracheal tube. Ventilation was controlled with $\mathrm{O}_{2}: \mathrm{N}_{2} \mathrm{O}$, halothane $0.5-1 \%$ and vecuronium or d-tubocurarine. Small incremental doses of meperidine were used to supplement analgesia.

Intraoperative monitoring included heart-rate, continuous ECG, non-invasive blood pressure (oscillotonometer), end-tidal carbon-dioxide and pulse oximetry.

At the end of surgery, neuromuscular blockade was reversed with neostigmine and atropine or glycopyrrolate. Recovery was uneventful in all patients.

\section{Discussion}

The Sturge-Weber syndrome, also known as encephalotrigeminal angiomatosis, is characterised by congenital skin angiomas. No pattern of inheritance is generally accepted. Angiomas are frequently unilateral with faciotrigeminal distribution but may be bilateral. It may also be found on the trunk and extremities and involve the mucous membrane of nose, gingiva, palate, tongue, larynx and trachea. Vascular changes are also found in the dura, leptomeninges, brain, pituitary, thymus, lung, spleen and lymph nodes. ${ }^{3,4}$ Ipsilateral hemi-hypertrophy of face is often present. All our patients had port wine stains on the face. No consistent pattern of haemangioma was observed in our patients. It was generalized in two patients, it was present on the face and limbs in two patients and on the face only in seven patients. Two patients had haemangiomas on the face and opposite side of the body (Table). Two patients had haemangiomas on the hard and soft palate.

Cerebral atrophy with destruction of neurons is also characteristic of Sturge-Weber disease. Two mechanisms are cited as being responsible: destruction of the parenchyma by the calcium deposits which gradually increase in number and size and gradually replace the cerebral tissue; or granule formation in the capillary walls leading to total calcification of the intima and media. ${ }^{7,8}$ Enzmann et al. $1977^{9}$ reported ipsilateral enlargement of the hemicranium with ipsilateral cerebral atrophy.

Convulsions occur in most patients and start before the first year of life. Convulsions may be generalized or focal, contra-lateral to the facial naevus. They may be intractable leading to progressive mental retardation. Hemiparesis, a frequent focal neurological sign, may be evident at birth and may progress with an increasing number of convulsions. Retardation of growth in girth and length of the limb on the hemiparetic side is common. Hemiparesis with hemiatrophy has also been reported. $7,10,11$ Facial hypertrophy is present in the territory below and adjacent to the cutaneous angioma. ${ }^{10,12}$ This consists of 
a hyperplasia affecting the soft tissues and the skeleton with thickening and infiltration of the skin even in area unaffected by the angioma.

Combinations of the Sturge-Weber disease with other phakomatoses have often been noted. In most cases, the angioma and hypertrophy coincide in an arm or leg in the Klippel-Trenaunay syndrome and on one side of the face in Sturge-Weber syndrome but exceptions and dissociated forms have been noted. Kramer $(1963)^{13}$ reported combinations of Sturge-Weber disease with the KlippelTrenaunay syndrome. Enzmann et al. (1977) ${ }^{9}$ reported a case of Sturge-Weber syndrome with features of the Klippel-Trenaunay-Weber syndrome consisting of discoloured skin and hypertrophy of soft tissues and the bone in the extremities. Hemihypertrophy of the body was present in two patients, whereas one patient had hypertrophy of the lower limb. Hemihypertrophy of face was present in two patients but none of our patients presented with hemiparesis. One patient had a left facial palsy. Six patients (46.2\%) had convulsions of generalized tonic-clonic type, and were receiving anti-convulsant medication. Two patients were mentally retarded.

Subarachnoid and subdural haemorrhages may occur but are uncommon. Heart failure occurs rarely and is due to shunting through the intracranial angiomas. ${ }^{14} \mathrm{Re}$ current thrombotic episodes producing gradual loss of function may require use of anti-platelet agents. ${ }^{15}$

Patients may exhibit intracranial calcification on skull $x$-ray, which has the characteristic pattern of a parallel serpentine configuration known as the "tram sign" or the "railroad sign." The cortical calcifications are seen in 20\% of cases 11 and are rarely seen before two years of age ${ }^{16}$ though they have been reported at birth. ${ }^{17}$ They are usually unilateral, related to occipital or occipito-parietal lobes and may also occur in frontal lobe. ${ }^{7,8}$ Minimal cerebral involvement is difficult to detect and can only be diagnosed by angiography or contrast enhanced CT scan. ${ }^{9,16}$ A skull $x$-ray was done in all our patients: none showed intracranial calcification.

Congenital glaucoma is present in $33 \%$ of patients with the Sturge-Weber syndrome. ${ }^{18,19}$ It is thought to develop only when the cutaneous angioma involves the eyelids or the conjunctiva, but exceptions exist. Bilateral cases are rare and may occur when the vascular malformation is widespread. Of these cases $75 \%$ develop buophthalmos, marked telangiectasis of the conjunctiva and varicosities of the retinal vessels and choroidal haemangioma. Patients may show heterochromia of the iris, spontaneous dislocation of the lens, strabismus, optic atrophy and retinal detachment. ${ }^{18-20}$ All our patients, except one, had ocular manifestations; ten patients presented with glaucoma; of these, five had buophthalmos. Two patients had megalo-cornea.
Angiomatous changes have been reported in the pituitary, thyroid, thymus, lungs, spleen, testes and lymphnodes. Congenital cardiac malformations including septal defects, valvular stenosis and great vessels transposition have also been reported. ${ }^{3,5,10,18}$ Histological studies have shown that near the primary formation, secondary changes appear in the pathological vessels and in tissue invaded by the angiomatosis. These changes may be due to the consequences of the micropragia of the pathological blood vessels, which results in fibrosis, hyaline degeneration, dilatation and calcification of the walls; or they may result from circulatory and metabolic abnormalities in the angiomatous tissues which lead to degeneration and sclerosis of the vessels. Circulatory insufficiency might develop in certain organs, e.g., the liver or the pancreas, thus causing secondary metabolic and clinical disorders. 3,5

Children with Sturge-Weber syndrome may be submitted to periodic examination of the eyes and respiratory tract. They may require surgery of associated anomalies depending upon the involvement of various organs. Occasionally surgical ablation of the affected cerebral lobe may be required to control intractable seizures associated with severe mental retardation and hemiparesis. ${ }^{21,22}$ The anaesthetic management includes careful assessment for associated anomalies. They tolerate anaesthesia well but intubation difficulties may exist due to angioma of lip, oral cavity, tongue, larynx and trachea. Uncontrolled haemorrhage may result from perforation of vascular lesions. Tracheal intubation should, therefore, be performed with soft, non-stylleted, well-lubricated endotracheal tubes. Careful tracheo-bronchial suction is also mandatory.

Ocular manifestations may require the avoidance of anaesthetic agents which may increase intraocular pressure (IOP). Straining, bucking and obstructed airways during induction or emergence may increase intraocular as well as intracranial pressure. ${ }^{24}$ This increase in intracranial pressure can result in intracranial haemorrhage from associated haemangiomatous lesions. Three patients in this received succinylcholine to facilitate tracheal intubation. In two patients, IOP was already controlled with acetazolamide. Further thiopentone was used for induction and the larynx was sprayed with $4 \%$ lignocaine before endotracheal intubation. The other patient did not show a raised IOP. We encountered no problem or complications in anaesthetic management, which can be attributed to careful screening, monitoring and anaesthetic management.

We conclude that patients with Sturge-Weber syndrome should be carefully evaluated for associated anomalies. The anaesthetic management should be planned in such a way as to avoid trauma to the haemangiomatous 
lesions and rise in intra-ocular and intra-cranial pressure.

Careful intubation and extubation are mandatory.

\section{References}

I Sturge WA. A case of partial epilepsy, apparently due to a lesion of one of the vaso-motor centres of the brain. Transactions of the Clinical Society of London 1879; 12: 162-7.

2 Weber FP. A note on the association of extensive haemangiomatous naevus of the skin with cerebral (meningeal) haemangioma, especially cases of facial vascular naevus with contra-lateral hemiplegia. Proceedings of the Royal Society of Medicine 1929; 22: 431.

3 Schmitt J. Visceral aspects of the phakomatosis. In: Vinken PJ, Bruyn GW (Eds.). Handbook of Clinical Neurology, Volume 14. Amsterdam: North Holland Publishing Co., 1972; 668-730.

4 Alexander GL. Sturge-Weber syndrome. In: Vinken PJ, Bruyn GW (Eds.). Handbook of Clinical Neurology, Volume 14, Amsterdam: North Holland Publ. Co., 1972: 223-40.

5 Wohlwill FJ, Yakovlev PI. Histopathology of meningofacial angiomatosis (Sturge-Weber disease), Report of four cases. J Neuropathol Exp Neurol 1957; 16: 341-64.

6 Martz DG, Schreibman DL, Matijasko MJ. Neurological diseases. In: Katz J, Benumof JL, Kadis LB (Eds.). Anesthesia and Uncommon Diseases, 3rd edition, Philadelphia: W.B. Saunders Co., 1990; 578-9.

7 Norman MG, Schoene WC. The ultrastructure of SturgeWeber disease. Acta Neuropathol (Berl) 1977; 37: 199-205.

8 Alexander GL, Norman MG. The Sturge-Weber Syndrome, Bristol; John Wright and Son, 1960; 55-78.

9 Enzmann DR, Hayward RW, Norman D, Dunn RP. Cranial computed tomographic scan appearance of SturgeWeber disease: unusual presentation. Radiology 1977; 122: $721-4$.

10 Yokovlev PI, Guthrie RH. Congenital ectodermoses (neurocutaneous syndromes) in epileptic patients. Archives of Neurology Psychiatry (Chicago) 1931; 26: 1145-97.

11 Poser CM, Tareras JM. Cerebral angiography in encephalotrigeminal angiomatosis. Radiology 1957; 68: 327-36.

12 Recondo JD, Haguenauo M. Phakomatoses - Neuropathology. In: Vinken PJ, Brayo GW (Eds.). Handbook of Clinical Neurology, Volume 14, Amsterdam, North Holland Publishing Co., 1972; 65-9.

13 Kramer $\boldsymbol{W}$. Klippel Trenaunay Syndrome. In: Vinken PJ, Bruyn GW (Eds.). Handbook of Clinical Neurology, Volume 14. Amsterdam: North Holland Publishing Co., 1972; 397.

14 Anderson FH, Duncan GW. Sturge-Weber disease with subarachnoid hemorrhage. Stroke 1974; 5: 509-11.

15 Garcia JC, Roach ES, McLean WT. Recurrent thrombotic deterioration in Sturge-Weber Syndrome. Child's Brain 1981; 8: 427-33.
16 Bentson JR, Wilson GH, Newton TH. Cerebral venous drainage pattern of the Sturge-Weber Syndrome. Radiology 1971; 101, 111-8.

17 Kitahara T, Yutaka M. A case of Sturge-Weber disease with epilepsy and intracranial calcification at the neonatal period. Eur Neurol 1978; 17; 8-12.

18 Roizon L, Gold G, Berman HH, Bonafede VI. Congenital vascular anomalies and their histopathology in SturgeWeber-Dimitri syndrome. J Neuropathol Exp Neurol 1959; 18: 75-97.

19 Pheleps $C D$. The pathogenesis of glaucoma in SturgeWeber Syndrome. Ophthalmology 1978; 85: 276-81.

20 Hoyt $C$. Phakomatosis. In: Taylor D (Ed.). Pediatric Ophthalmology. Boston: Blackwell Scientific Publications 1990; 586-7.

21 Farrell MA, Derosa MJ, Curran JG, et al. Neuropathologic findings in cortical resections (including hemispherectomies) performed for the treatment of intractable childhood epilepsy. Acta Neuropathol (Berl) 1992; 83: 246-59.

22 Dietrich RB, el Saden S, Chugani HT, Bentson J, Peacock WJ. Resective surgery for intractable epilepsy in children: radiologic evaluation. AJNR Am J Neuroradiol 1991; 12: 1149-58.

23 Ward CF. Paediatric head and neck syndrome. In: Katz J, Steward DJ (Eds.). Anaesthesia and Uncommon Pediatric Disease. Philadelphia: W.B. Saunders, 1987; 271.

24 Donlon JV. Anesthesia and eye, nose and throat surgery. In: Miller RD (Ed.). Anesthesia, 3rd edition. New York: Churchill Livingstone, 1990: 2004-5. 